\title{
Investigation of the Physical, Chemical Characteristics and Microbial Contamination of the Indoor Swimming Pools
}

\author{
Kapalı Yüzme Havuzlarının Fiziksel, Kimyasal Özelliklerinin ve \\ Mikrobiyal Kontaminasyonlarının Araştırılması
}

\begin{abstract}
(1) Fatemeh Ghasemi ${ }^{1}$, (1) Gholam Reza Hatam², (1) Foroozandeh Zaravar ${ }^{3}$, (1) Jalal Mardaneh", (1) Hadis Jafarian ${ }^{1}$, (1D Pejman Abbasi ${ }^{1}$, (1) Hamid Reza Khorrami ${ }^{5}$, (1) Parisa Badiee ${ }^{1}$

${ }^{1}$ Shiraz University of Medical Sciences, Prof. Alborzi Clinical Microbiology Research Center, Shiraz, Iran ${ }^{2}$ Shiraz University of Medical Sciences, Social Determinants of Health Research Center, Shiraz, Iran ${ }^{3}$ Shiraz University of Medical Sciences, School of Paramedical Sciences, Shiraz, Iran ${ }^{4}$ Gonabad University of Medical Sciences Faculty of Medicine, Department of Microbiology, Gonabad, Iran ${ }^{5}$ Shiraz University of Medical Sciences Faculty of Medicine, Department of Parasitology and Mycology, Shiraz, Iran
\end{abstract}

Cite this article as: Ghasemi F, Hatam GR, Zaravar F, Mardaneh J, Jafarian H, Abbasi P, Khorrami HR, Badiee P. Investigation of the Physical, Chemical Characteristics and Microbial Contamination of the Indoor Swimming Pools. Turkiye Parazitol Derg. 2019;43(3): 130-4.

\begin{abstract}
Objective: The aim of this study was to investigate the physical, chemical and microbiological contamination of indoor swimming pools.

Methods: Pool water specimens were collected using a plastic polypropylene sterilized bottle. The physical and chemical qualities of the waters were analyzed in terms of temperature, turbidity, $\mathrm{pH}$, and free residual chlorine, with the standard methods for the examination of water. Bacteriological (routine methods) and parasitological (molecular methods) tests were carried out on pools water.

Results: The mean temperature, $\mathrm{pH}$, and residual chlorine of the indoor pools were $31.2{ }^{\circ} \mathrm{C}, 7.6$ and $1.5 \mathrm{mg} / \mathrm{L}$, respectively. Turbidity was not observed in any of the pools. The $\mathrm{pH}$ and temperature values were in standard ranges in $92.3 \%$ and $15.4 \%$ of the waters of swimming pools, respectively. The prevalence rates of bacterial and amoebic contaminations of the water in the swimming pools were $53.8 \%$ and $46.2 \%$, respectively. One pool $(7.7 \%)$ was contaminated with both bacteria and amoeba. Streptococcus viridans, Staphylococcus epidermidis, Pseudomonas stutzeri, Cryptosporidium and Bacillus spp. were isolated from the pool waters.

Conclusion: In this study, some microorganisms were identified from the water pools. Effective management of swimming pools and proper control of the physical, chemical and microbiological property of water pools can produce the healthy recreational activity.
\end{abstract}

Keywords: Swimming pools, pseudomona, cryptosporidium, chlorine

Öz

Amaç: Bu çalışmanın amacı kapalı yüzme havuzlarının fiziksel, kimyasal ve mikrobiyolojik kirlenmelerini araştırmaktır.

Yöntemler: Havuz suyu örnekleri plastik polipropilen sterilize edilmiş bir şişe kullanılarak toplandı. Suların fiziksel ve kimyasal özellikleri, suyun incelenmesinde kullanılan standart yöntemler ile sıcaklık, bulanıklık, pH ve serbest artık klor açısından analiz edildi. Havuz sularında bakteriyolojik (rutin yöntemler) ve parazitolojik (moleküler yöntemler) çalışmalar yapılmıştır.

Bulgular: Kapalı havuzların sıcaklık, $\mathrm{pH}$ ve artık klor ortalamaları sırasıyla $31,2{ }^{\circ} \mathrm{C}, 7,6$ ve $1,5 \mathrm{mg} / \mathrm{L}$ idi. Havuzların hiçbirinde bulanıklık gözlenmedi. PH ve sıcaklık değerleri yüzme havuzlarının sırasıyla \%92,3 ve \%15,4’ünde istenilen aralıktaydı. Yüzme havuzlarında suyun bakteriyel ve amipli kirlenme sıklığ sırasıyla \%53,8 ve \%46,2'dir. Bir havuz $(\% 7,7)$ hem bakteri hem de amip ile kirlenmiștir. Streptococcus viridans, Staphylococcus epidermidis, Pseudomonas stutzeri, Cryptosporidium spp. ve Bacillus spp. havuz sularından izole edilmiştir.

Sonuç: Bu çalışmada, su havuzlarından bazı mikroorganizmalar tanımlanmıştır. Yüzme havuzlarının etkin yönetimi ve su havuzlarının fiziksel, kimyasal ve mikrobiyolojik özelliklerinin uygun şekilde kontrolü sağlıklı rekreasyon aktivitesini sağlayabilir. Anahtar Kelimeler: Yüzme havuzları, pseudomonas, cryptosporidium, klor 


\section{INTRODUCTION}

People attend swimming facilities for practice on water-related sports and recreational activities, rehabilitative treatment, and relaxant sports. Microbial contamination and variation on physical quality were reported in the literature (1-3). Various diseases may be transmitted to the swimmers by exposure to physical, chemical and microbiological agents of the pools. Such diseases may be related to the hygiene in pool environment and water, temperature, $\mathrm{pH}$, and residual chlorine levels.

Microbial contamination of the pool water is resulted by fecal contamination of the pool environment and water by bathers and swimmers, the release of an accidental diarrheic stool or direct animal contamination like rodents. In recent years, systemic microbial infections including parasitic or bacterial diarrhea, typhoid, hepatitis and cholera caused by swallowing the contaminated water have been reported especially in immunocompromised patients (4-6). Contamination of swimming pools with microbiological parameters including Pseudomonas aeruginosa, Staphylococcus aureus, Staphylococcus epidermidis, and Escherichia coli have also been reported in the literature $(1,2)$. Other pathogenic microorganisms such as protozoa may also be presented in recreational waters, which include Naegleria fowleri, Giardia lamblia, Trichomonas vaginalis, Plasmodium, Acanthamoeba, and Cryptosporidium spp. $(7,8)$. In the patients with weakened or depressed immune systems and those taking certain immunosuppressant, swimming in the public pools can cause severe diseases. To provide healthy swimming pools and prevent swimmers from communicable infectious diseases, making a safe swimming environment free from microorganisms is necessary. The aim of this study was to investigate the physical and chemical parameters, and parasitic and bacterial contamination in indoor swimming pools waters. The findings were compared with local and international guidelines.

\section{METHODS}

\section{Sampling}

This cross-sectional study was conducted in 13 public recreation indoor swimming pools during spring and summer of 2016. Pool water specimens were collected in the morning before starting the swimming and after decontamination of the pools. Water samples (8 liters) were collected using a manual plastic polypropylene sterilized bottle, at approximately 1 meter below the surface of the pool water and transferred to the microbiological laboratory. The physical and chemical qualities of the waters were analyzed in terms of temperature, turbidity, $\mathrm{pH}$ and free residual chlorine, according to the standard methods for the examination of water (9). The samples were transferred to the laboratory in a cool box and microbiological analysis was performed within 2 hours. The information about the pool sanitation and usage of disinfectants was collected from the chief of the pools. The temperature was measured using a digital thermometer, and chlorine residual and $\mathrm{pH}$ were evaluated onsite by Chlorine- $\mathrm{pH}$ kit (Pool Tester, Poison Centers Berlin, Germany). The turbidity of the waters was evaluated by spectrophotometer (Biowave WPA, UK).

The water samples were filtrated by filter paper with $47 \mathrm{~mm}$ diameter (0.2 $\mu \mathrm{m}$-pore-size) and vacuum motor (Sartorius Stedim, Biotech GmbH, Germany), immediately following the collection (Sartorius Stedim Biotech GmbH, Germany). The filter papers were divided into two parts; one for bacteriological and the other for parasitological studies (DNA extraction).

\section{Bacteriological Study}

In the first step, filter papers were cultured in brain heart infusion broth and incubated at $35 \pm 2{ }^{\circ} \mathrm{C}$ for $24-48$ hours. After an incubation period, $100 \mu \mathrm{L}$ of the medium was cultured on each of following microbiological media including blood agar, MacConkey agar, and eosin methylene blue agar. The plates were incubated at $35 \pm 2{ }^{\circ} \mathrm{C}$ and evaluated for bacterial growth every day until one week. For final identification of isolates, the supplementary morphological and chemical tests were used. All of the media were purchased from Merck Company (Darmstadt, Germany).

\section{Parasitological Study}

This part of the study was carried out using molecular methods. Filter papers were washed with $2 \mathrm{~mL}$ of phosphate-buffered saline by mild shaking. The residual fluid was centrifuged at $3000 \mathrm{rpm}$ for 5 minutes. DNA was extracted from sediment cells using the Commercial kit (Invisorb Spin DNA Mini Kit- Stratec, Germany), according to the manufacturer's instructions. Polymerase chain reacton (PCR) tests for Acanthamoeba spp. (10), T. vaginalis (11), Entamoeba histolytica (12), G. lamblia (13), and Cryptosporidium spp. (14) were performed on pool water samples. In Table 1, the primers and related references were presented, and the PCR amplifications were performed, accordingly.

Table 1. The primers used in this study for identification of Amoeba in 13 swimming pools

\begin{tabular}{|l|l|}
\hline \multicolumn{2}{|l|}{ Giardia lamblia (13) } \\
\hline AS1 & CGACCGGGAGACACGCCC \\
\hline AS2 & AGGACTGCATATCACGGC \\
\hline SG3 & AGAGCAGCCGATCCCCCG \\
\hline SG4 & AATTGGAGGCTGACTGTG \\
\hline Entamoeba histolytica (12) \\
\hline E1 & TAAGATGCACGAGAGCGAAA \\
\hline E2 & GTACAAAGGGCAGGGACGTA \\
\hline EH1 & AAGCATTGTTTCTAGATCTGAG \\
\hline EH2 & AAGAGGTCTAACCGAAATTAG \\
\hline Acanthamoeba spp. (10) \\
\hline JDP1 & GGCCCAGATCGTTTACCGTGAA \\
\hline JDP2 & TCTCACAAGCTGCTAGGGGAGTCA \\
\hline A1 & AACGATGCCGACCAGCGATTA \\
\hline Trichomonas vaginalis (11) \\
\hline OP1 & GTGAAAATCTCATTGGGGTATTAACTT \\
\hline OP2 & GTTTTATTTATCACTGGAAAATAACGCTT \\
\hline IP1 & AACATCCCCAACATCTT \\
\hline IP2 & CCATTCTTTTAGACCCTT \\
\hline Cryptosporidium spp. (14) \\
\hline SSU- F2 & TTCTAGAGCTAATACATGCG \\
\hline SSU- R2 & CCCATTTCCTTCGAAACAGGA \\
\hline SSU- F3 & GGAAGGGTTGTATTTATTAGATAAAG \\
\hline SSU- R3 & AAGGAGTAAGGAACAACCTCCA \\
\hline
\end{tabular}


Table 2. The physicochemical and microbiologic property of 13 swimming pools

\begin{tabular}{|l|l|l|l|l|l|}
\hline $\begin{array}{l}\text { Swimming pools } \\
\text { number }\end{array}$ & Temperature ${ }^{\mathbf{C}} \mathbf{C}$ & $\mathbf{p H}$ & $\begin{array}{l}\text { Residual chlorine } \\
\mathbf{m g} / \mathbf{L}\end{array}$ & Bacteria species & Parasite species \\
\hline 1 & 33.0 & 7.8 & 1.0 & $\begin{array}{l}\text { Streptococcus viridans, } \\
\text { Staphylococcus epidermidis }\end{array}$ & - \\
\hline 2 & 31.0 & 7.8 & 2.0 & Staphylococcus epidermidis & - \\
\hline 3 & 33.0 & 7.6 & 2.0 & Bacillus spp. & - \\
\hline 4 & 33.0 & 7.2 & 2.0 & Bacillus spp. & - \\
\hline 5 & 34.0 & 7.6 & 0.1 & Pseudomonas stutzeri & - \\
\hline 6 & 32.0 & 7.6 & 0.1 & $\begin{array}{l}\text { Pseudomonas stutzeri } \\
\text { Bacillus spp. }\end{array}$ & Cryptosporidium spp. \\
\hline 7 & 30.0 & 7.8 & 3.0 & Staphylococcus epidermidis & - \\
\hline 8 & 32.0 & 7.6 & 1.5 & - & Cryptosporidium spp. \\
\hline 9 & 30.0 & 8.2 & 3.0 & - & Cryptosporidium spp. \\
\hline 10 & 30.0 & 7.6 & 1.0 & - & Cryptosporidium spp. \\
\hline 11 & 29.0 & 7.6 & 1.0 & - & - \\
\hline 12 & 29.0 & 7.8 & 1.0 & - & Cryptosporidium spp. \\
\hline 13 & 30.0 & 7.6 & 3.0 & Cryptosporidium spp. \\
\hline
\end{tabular}

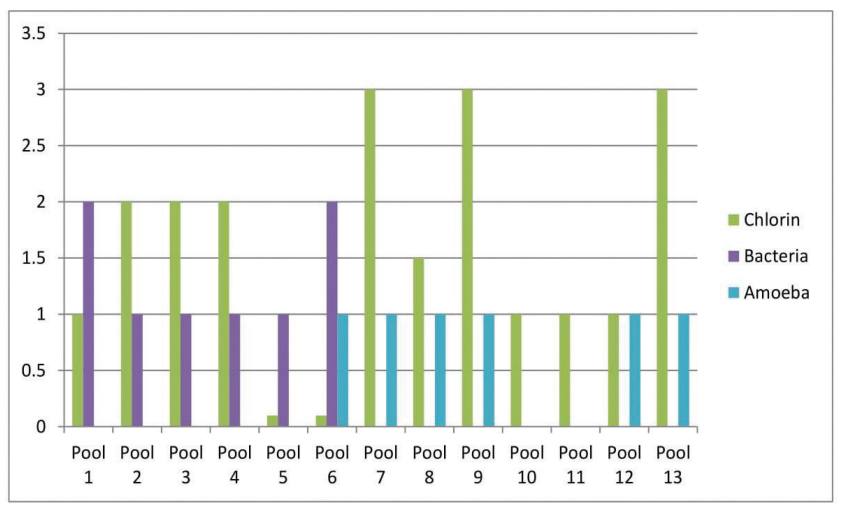

Figure 1. The relationship between residual chlorine and microbiology identification in 13 swimming pools

\section{Statistical analysis}

This study was descriptive and statistical analysis was not applicable.

\section{RESULTS}

In this study, all of the pools were disinfected manually. The mean of temperature, $\mathrm{pH}$, and residual chlorine of the 13 indoor pools were $31.2{ }^{\circ} \mathrm{C}$ (range $=29-34{ }^{\circ} \mathrm{C}$ ), 7.6 (range=7.2-7.6) and 1.5 (range=0.1-3) $\mathrm{mg} / \mathrm{L}$, respectively. Turbidity was not observed in any of the pools. Frequencies of the physicochemical parameters of the swimming pools are presented in Table 2. The $\mathrm{pH}$ values showed low fluctuations in all the investigated swimming pools, only one pool had a $\mathrm{pH}$ value equal to 8.2. The temperature was standard in $15.4 \%$ of the swimming pools. The prevalence rates of bacterial and amoebic contaminations of the water in the swimming pools were $7 / 13$ (53.8\%) and 6/13 (46.2\%), respectively, and one pool (7.7\%) was contaminated with Pseudomonas stutrezi, Bacillus spp., and Cryptosporidium spp. The contaminated isolates were Streptococcus viridans, Staphylococcus epidermidis, P. stutzeri,
Bacillus and Cryptosporidium spp. T. vaginalis, G. lamblia, E. histolytica, and Acanthamoeba spp. were not detected in any of the water samples analyzed by PCR methods. According to Figure 1, in pools with the low concentration of free chlorine, a high count of microorganisms was isolated.

\section{DISCUSSION}

Swimming pools may be contaminated with microorganisms associated with swimmers like fecal contamination of the water, accidental fecal release or residual fecal material on bodies, and non-fecal shedding like vomit, mucus, saliva, skin, mouth, and upper respiratory tract contamination. Some may cause a variety of respiratory, dermal or central nervous system infections or diseases $(4,5,15)$. Some studies have been investigated the quality of pool waters during the working days $(4,5)$. Also, some researcher believed the highest number of swimmers during holidays and weekend are young children (16), therefore the water sampling would be better evaluated in these times. In order to monitor the environmental effect of physicochemical and microbial program, we examined the water pool conditions when the pools were disinfected and suitable for swimmers. In this time, the disinfectants cannot appropriately clean the water pools and microbial contamination was presented.

The mean $\mathrm{pH}$ value of the water pools in this study was 7.6 (7.28.2), the ranges recommended by the Iranian Ministry of Health and Egyptian standard range are 7.2-7.8 and 7.2-8 (17,18). The $\mathrm{pH}$ value of the pools water in Shahrekord city was reported $8.08 \pm 0.29$ (2). The $\mathrm{pH}$ level and the residual chlorine measuring are important factors in the management of the pools because by increasing the $\mathrm{pH}$, only a low percentage of residual chlorine changes into hypochlorous (4). Only one pool in this study had $\mathrm{pH}$ value equal to 8.2 and more than the standard range.

The standard turbidity of water in World Health Organization (WHO) is less than 0.5 Nephelometric Turbidity Units (NTU) (4), no turbidity of water pool was seen in this study. Water analysis in Lutz and Lee indicated low turbidity about 0.1-0.6 NTU (19). According to WHO standard breakpoints, the suitable water 
temperatures for swimmers range from 26 to $30{ }^{\circ} \mathrm{C}$, respectively (4). In this study, the mean temperature of water pools was 31.2 ${ }^{\circ} \mathrm{C}\left(29-34{ }^{\circ} \mathrm{C}\right)$. Swimming pools temperatures ranged from 25.9 $-32.4{ }^{\circ} \mathrm{C}$ and hot tub temperature $38.7-39.3^{\circ} \mathrm{C}$ were reported (18). As revealed, the temperature was not in standard range in $11 / 13$ (84.6\%) swimming pools in the present study, and this condition is not comfortable for swimmers.

For the prevention of the contamination, water pools are treated with disinfectants such as chlorine compounds and/or ozone. Research studies showed that such disinfectants cannot prevent the pool water from the microorganisms $(4,5)$. The mean residual chlorine in this study was $1.5(0.1-3) \mathrm{mg} / \mathrm{L}$, but in two pools the residual chlorine level was under the standard level. In ElSalam (20) $43.3 \%$ of the water samples were unacceptable for residual chlorine. The low concentration of residual chlorine was insufficient to eliminate all bacteria or free-living ameba within the swimming pools. Chlorine is considered the best disinfectant for swimming pool water. In the present study, most of the pools used chlorine gas and two pools used ozone combined with chlorine, according to Graph 1, in pools with the low concentration of free chlorine, a high count of microorganisms was isolated.

Diagnosis of microbial organisms with PCR assay was reported in the literature (21-23) and in the present study; we used this method to identify amoebic contaminations of the pools. In the current study, T. vaginalis, G. lamblia, E. histolytica, and Acanthamoeba spp. were not detected in any of the water samples, but Cryptosporidium spp. was detected in 6 out of the 13 pools. We did not find any study which examined swimming pools by PCR methods. According to standard protocols, swimming pools must be free from any protozoa. In the study by El-Salam (20), $3.3 \%(1 / 30)$ of the examined water samples had Cryptosporidium oocysts, and $6.6 \%$ (2/30 examined pools) had G. lamblia cysts. In Italian investigation of 10 chlorinated swimming pools, free chlorine levels were approximately $1 \mathrm{mg} / \mathrm{L}$, and Cryptosporidium and Giardia were found in 3\% of the pool water samples (24). Acanthamoeba can be found in all aquatic environments, including disinfected swimming pools. Acanthamoeba cysts are highly resistant to extremes of temperature, disinfection, and desiccation. The cysts will retain viability from $-20^{\circ} \mathrm{C}$ and $56^{\circ} \mathrm{C}$. In the untreated state, Acanthamoeba keratitis can lead to permanent blindness (7). Giardia cysts and Cryptosporidium oocysts can cause infection in humans and result in diarrhea with accompanying abdominal cramps and vomiting. Giardia cyst is very resistant to many disinfectants, including chlorine. Cryptosporidium is much more resistant to chlorine than Giardia cysts. Cryptosporidium requires chlorine concentrations of $30 \mathrm{mg} / \mathrm{L}$ for $240 \mathrm{~min}$ (at $\mathrm{pH}$ 7 and a temperature of $25^{\circ} \mathrm{C}$ ) for achieving a $99 \%$ reduction (4). Isolation of Cryptosporidium in this study can be due to resistant of its oocysts.

In the present study, the prevalence of bacterial contaminations in the water of the swimming pools was $7 / 13$ (53.8\%), and S. viridans, S. epidermidis, P. stutzeri, and Bacillus spp. were isolated from the pool waters. The isolated bacteria from the swimming pools in the literature include Pseudomonas aeruginosa, Staphylococcus aureus, Legionella, and E. coli (2), and P. aeruginosa and Streptococcus spp. (20). The isolation of bacteria was reported with respect to water temperature and free chlorine (1). The water pools may be contaminated with Pseudomonas by swimmers or natural contamination. Pseudomonas is resistant to sodium hypochlorite that used for disinfecting pools, and it is considered to be an opportunistic microorganism involved in the urinary tract, wound, sepsis and bed sores infections $(17,25,26)$. That is able to grow in moist, warm conditions with low levels of organic nutrients. $P$. aeruginosa has intrinsic antimicrobial resistance due to low outer membrane permeability, an extensive efflux pump system and ability to spore production (27). Staphylococcus is a common skin organism which may be recovered from recreational waters. It may be considered as a risk indicator for skin, eye and ear diseases $(2,28,29)$. Coagulase-positive Staphylococcus strains have been found in chlorinated swimming pools. In Italy, in a study on chlorinated pools, where the free chlorine level varied between 0.8 and $1.2 \mathrm{mg} / \mathrm{L}, \mathrm{S}$. aureus was not recovered from water samples (24). Fecal Staphylococcus was not detected in any of the examined samples in El-Salam (20). In the present study, 1/13 of the studied pools were contaminated with P. stutzeri, Bacillus and Cryptosporidium spp. The level of the chlorine in this pool was very low.

\section{CONCLUSION}

In this study, before opening and after cleaning the pools, the physical and chemical properties of some indoor swimming pools were not optimal and some microorganisms were identified from the water pools. Effective management of swimming pools and proper control of disinfectant levels, water temperature, turbidity, $\mathrm{pH}$ and microbiological property can produce the healthy water for people recreational activity.

\section{* Ethics}

Ethics Committee Approval: Parisa Badiee, was approved by the "Local Research Ethics committee" of Prof. Alborzi Clinical Microbiology Research Center with ID EC94-2.

Informed Consent: This study was not involving human or animal participants, and we only evaluate the environmental samples.

Peer-review: Externally and internally peer-reviewed.

\section{* Authorship Contributions}

Concept: P.B., F.G., Design: G.R.H., J.M., H.R.K., Data Collection or Processing: G.R.H., H.R.K., J.M., P.A., Analysis or Interpretation: P.B., G.R.H., J.M., H.R.K., Literature Search: P.A., F.Z., F.G., Writing: P.B., F.G.

Conflict of Interest: No conflict of interest was declared by the authors.

Financial Disclosure: The authors declared that this study received no financial support.

\section{REFERENCES}

1. Sima R, Mohammad Ali A, Leila I, Mahmood S, Hamid Reza G, Mohammad P. Assessment of microbial contamination and physicochemical condition of public swimming pools in Kashan, Iran. Jundishapur J Microbiol 2012;5:450-55.

2. Fadaei A, Amiri M. Comparison of chemical, biological and physical quality assessment of indoor swimming pools in Shahrekord City, Iran in 2013. Glob J Health Sci 2013;7:240-8.

3. Simard S, Tardif R, Rodriguez MJ. Variability of chlorination by-product occurrence in water of indoor and outdoor swimming pools. Water Res 2013;47:1763-72.

4. World Health Organization. Addendum to the WHO guidelines for safe recreational water environments. Coastal and fresh waters: list of agreed updates; 2009;1. 
5. Papadopoulou C, Economou V, Sakkas H, Gousia P, Giannakopoulos $\mathrm{X}$, Dontorou $\mathrm{C}$, et al. Microbiological quality of indoor and outdoor swimming pools in Greece: investigation of the antibiotic resistance of the bacterial isolates. Int J Hyg Environ Health 2008;211:385-97.

6. Agholi M, Hatam GR, Motazedian MH. HIV/AIDS-associated opportunistic protozoal diarrhea. AIDS Res Hum Retroviruses 2013;29:35-41.

7. Ondriska F, Mrva M, Lichvár M, Ziak P, Murgasová Z, Nohýnková E. First cases of Acanthamoeba keratitis in Slovakia. Ann Agric Environ Med 2004;11:335-41.

8. Pereira-Neves A, Benchimol M. Trichomonas vaginalis: in vitro survival in swimming pool water samples. Exp Parasitol 2008;118:438-41.

9. Eatson DL, Clesceri S, Rice EW, Greenberg AE. Standard methods for the examination of water and wastewater. 21st edn edn. USA: Centennial Edition; 2005.p.4-138.

10. Dhivya S, Madhavan HN, Rao CM, Rao KS, Ramchander PV, Therese KL, et al. Comparison of a novel semi-nested polymerase chain reaction (PCR) with a uniplex PCR for the detection of Acanthamoeba genome in corneal scrapings. Parasitol Res 2007;100:1303-9.

11. Shaio MF, Lin P-R, Liu JY. Colorimetric one-tube nested PCR for detection of Trichomonas vaginalis in vaginal discharge. J Clin Microbiol 1997;35:132-8.

12. Khairnar K, Parija SC. A novel nested multiplex polymerase chain reaction (PCR) assay for differential detection of Entamoeba histolytica, E. moshkovskii and E. dispar DNA in stool samples. BMC Microbiol 2007;7:47.

13. Ghosh S, Debnath A, Sil A, De S, Chattopadhyay DJ, Das P. PCR detection of Giardia lamblia in stool: targeting intergenic spacer region of multicopy rRNA gene. Mol Cell Probes 2000;14:181-9.

14. Xiao L, Fayer R, Ryan U, Upton SJ. Cryptosporidium taxonomy: recent advances and implications for public health. Clin Microbiol Rev 2004;17:72-97.

15. Nichols G. Infection risks from water in natural and man-made environments. Euro Surveill 2006;11:1-2.

16. Rabi A, Khader Y, Alkafajei A, Aqoulah AA. Sanitary conditions of public swimming pools in Amman, Jordan. Int J Environ Res Public Health 2007;4:301-6.

17. Islamic Republic of Iran. Ministry of Health and Medical Education (2013). A Gide to monitoring of Swimming Pools and Coastol Water; 2013.
18. Egyptian Ministry of Health. Egyptian fresh water swimming pool standards. Decree No. 418 for year 1995. Cairo: Government Printing House; 1995.

19. Lutz JK, Lee J. Prevalence and antimicrobial-resistance of Pseudomonas aeruginosa in swimming pools and hot tubs. Int J Environ Res Public Health 2011;8:554-64.

20. El-Salam MMA. Assessment of water quality of some swimming pools: a case study in Alexandria, Egypt. Environ Monit Assess 2012;184:7395406.

21. Badiee P, Kordbacheh P, Alborzi A, Zakernia M, Haddadi P. Early detection of systemic candidiasis in the whole blood of patients with hematologic malignancies. Jpn J Infect Dis 2009;62:1-5.

22. Badiee P, Alborzi A, Shakiba E, Ziyaeyan M, Pourabbas B. Molecular diagnosis of Aspergillus endocarditis after cardiac surgery. J Med Microbiol 2009;58:192-5.

23. Agholi M, Hatam GR, Motazedian MH. Microsporidia and coccidia as causes of persistence diarrhea among liver transplant children: incidence rate and species/genotypes. Pediatr Infect Dis J 2013;32:185-7.

24. Bonadonna L, Briancesco R, Magini V, Orsini M, Romano-Spica V. A preliminary investigation on the occurrence of protozoa in swimming pools in Italy. Ann Ig 2004;16:709-19.

25. Seyfried PL, Fraser DJ. Persistence of Pseudomonas aeruginosa in chlorinated swimming pools. Can J Microbiol 1980;26:350-5.

26. Kato K, Iwai S, Kumasaka K, Horikoshi A, Inada S, Inamatsu T, et al. Survey of antibiotic resistance in Pseudomonas aeruginosa by the Tokyo Johoku Association of Pseudomonas Studies. J Infect Chemother 2001;7:258-62.

27. Lister PD, Wolter DJ, Hanson ND. Antibacterial-resistant Pseudomonas aeruginosa: clinical impact and complex regulation of chromosomally encoded resistance mechanisms. Clin Microbiol Rev 2009;22:582-610.

28. Valeriani F, Giampaoli S, Buggiotti L, Gianfranceschi G, Romano Spica V. Molecular enrichment for detection of S. aureus in recreational waters. Water Sci Technol 2012;66:2305-10.

29. da Costa Carmo MA, Chavasco JK, Franzolın SD, Beijo LA, Weckwerth $\mathrm{PH}$. Microbiological assessment of dentists hands in clinical performance. Afr J Microbiol Res 2014;8:797-802. 